\title{
ÉTICA E EDUCAC̃̃̃ CLÁSSICA: VIRTUDE E FELICIDADE NO JUSTO MEIO
}

\author{
Carlota Boto *
}

(...) os seres humanos experimentam prazer compartilhando sentimentos, e sofrem quando não podem compartilhálos... Ter bons sentimentos significa, em poucas palavras, saber comportar-se, saber o que fazer quando a dor ou a al egria nos invadem. Possuir a perspicácia e a sensibilidade suficientes para entender 0 que sucede com o outro, e 0 autodomínio e a delicadeza imprescindíveis para a exteriorização dos nossos afetos.

(VIctoria Cam PS, Virtudespúblicas)

RESU M 0: 0 presente estudo debruça-se sobre a interface do problema educativo com a problemática da ética, compreendendo a pedagogia com a arte/ciência voltada para a busca do bem educar/instruir/ formar. Para tanto, o texto mobilizará conceitos da concepção ética da Aristóteles; e, na atmosfera mental da G récia clássica, recorre-se ao termo específico grego etransdisciplinar na origem: paideia. A seguir, este ensaio procura pontuar al guns aspectos da concepção iluminista a propósito do tema, valendo-se da noção kantiana de imperativo categórico, a qual teria sido precedida pelo parecer de Rousseau, segundo o qual a vontade - e não a razão - seria a marca distintiva do gênero humano no ambiente natural. A idéia de Piaget de uma ética da reciprocidade também é aqui mobilizada. Abordando diacronicamente a temática, serão analisados conceitos de autores clássicos no debate da relação entre educação e ética, com destaque para o sentido conferido por $\mathrm{H}$ anna Arendt para a autoridade como critério distintivo da relação assi métrica entre o educador (as gerações adultas de maneira geral) e os estudantes (ou as novas gerações). Arendt defende, como conceito e pressuposto operatório, a dimensão necessariamente conservadora do ato educativo: competeao educador preservar do mundo as novas gerações e preservar o mundo das novas gerações - para que estas não destruam o suporte e 0 acervo cultural acumulados.

Palavras chave: Educação; Ética; Filosofia da Educação; Pedagogia.

* Professora Efetiva de H istória da Educação na Faculdade de Ciências e Letras da Universidade Estadual Paulista (U nesp - Campus de Araraquara). E-mail: carlotaboto@uol.com.br 


\section{Introdução}

A ação ética na matéria educacional tem sido objeto de freqüentes reflexões. Fervilha hoje um debate que, de tão intenso, torna-se esgarçado, desgastado, próximo do nível opiniático, quase um sogan de senso comum nestes anos de fronteiras: fronteiras de séculos e de utopias; fronteiras de paradigmas e de referências; fronteiras, enfim, de valores. Sobre ética e educação, nosso tempo, contudo, parece não ter nada de novo a dizer. Q uase tudo já foi dito. Será mesmo? 0 estudo da ética é sempre inseparável da discussão sobre a vida justa. $\mathrm{E}$ a vida justa como categoria só pode ser apreendida quando pensamos a realidade social: a vida com os outros; a interação coletiva; enfim, a esfera pública. D e algum modo, o pensamento a propósito da ética implica reflexões dela decorrentes, sobre temas como os da solidariedade, da tolerância, da responsabilidade, das identidades e dos direitos.

Como bem define M arilena Chauí (1994a, p. 340), o termo ética advém do sentido grego de ethos: "caráter, índole natural, temperamento". A ação ética ancora-se, pois, na intencionalidade da ação, na relação da consciência para consigo mesma, na integridade do ser humano frente a seus semelhantes. A sujeito moral é, por definição, aquele capaz de distinguir entre o bem e o mal; e, portanto, capaz de se desviar do caminho prescrito, capaz de decidir, de escolher, de deliberar - pelo reconhecimento da fronteira entre 0 justo e 0 injusto. A confluência entre o tema da ética e a matéria educativa se coloca justamente nessa intersecção entre a autonomia da vontade e a possível formação pedagógica que a habilita.

Viver sob parâmetros éticos requer a eleição de princípios do agir, em consonância com os quais se possa pautar a trajetória da vida. M as as escolhas não estão dadas à partida. É necessário - e recomendável - um exercício continuado para aprender a escolher, no plano dos valores. Em última análise, tal atitude de escolha e de aprendizado das escolhas perdura no decorrer de toda nossa vida. M as como poderemos nos valer das opções previamente efetuadas como referência e roteiros de ação em nossa vida cotidiana? Este ensaio procurará discorrer sobre algumas aproximações possíveis entre moralidade e educação do juízo moral, à luz de balizas clássicas a propósito tanto da matéria da ética quanto da perspectiva educacional. Para nos aproximarmos deste campo interdisciplinar e multifacetado, optamos por recorrer a um entrecruzamento da perspectiva de alguns autores contemporâneos acerca do tema, com a matriz analítica advinda de pensadores clássicos, selecionados do campo da fi- 
Iosofia, da educação e da teoria política, pela contribuição que deram ao debate ético. D essa maneira, compreendemos a possibilidade de reencontrarmos algumas das questões que, evocadas do passado na história do pensamento ocidental, interpelam nosso tempo e nossas atitudes no dia-a-dia, como atores da educação - professores e alunos. Retomando e recompondo modos de compreender o que poderíamos qualificar de educação ética, procuraremos refletir acerca de indagações intelectuais e morais postas pelo 0 cidente. Diferentes épocas; variadas matrizes de pensamento; distintas expressões intelectuais; procuraremos tomar por alicerce fundante dos autores aqui recordados a preocupação - comum a todos - quanto à possibilidade de compor o campo da ética, não como um dado natural e essencial, mas, sobretudo, como uma experiência apreendida, acumulada e pedagogicamente construída.

0 presente estudo tem o objetivo de se debruçar sobre a intersecção do problema educativo para com a problemática ética, compreendendo a pedagogia como uma arte/ciência historicamente voltada para a busca do bem educar/instruir/formar. Com tal propósito, o texto mobilizará conceitos expressos na ética de Aristóteles, particularmente sua acepção de vida boa e de justo meio. Ainda na atmosfera mental da G récia Clássica, recorre-se ao termo específico grego e transdisciplinar na origem: paideia - cujos sentidos múltiplos imbricam instrução, educação, formação, cultivo intelectual, cultura geral, civilização... A seguir, dever-seá pontuar alguns aspectos da concepção iluminista a propósito do tema, mediante 0 recurso à expressão kantiana de imperativo categórico, cujos significados gerais teriam sido precedidos pela concepção rousseauniana, segundo a qual a vontade - e não a razão - é a marca distintiva do gênero humano.

A idéia piagetiana de uma ética da reciprocidade também é aqui mobilizada, à luz de uma breve exposição de sua crença na analogia entre as relações adultas e os jogos travados na infância. N estes jogos infantis, para Piaget, as regras inventadas são exatamente necessariamente respeitadas pelo grupo social em jogo. U ma das mais respeitadas das normas espontâneas da criança seria, do ponto de vista de Piaget, a dimensão interativa da justiça distributiva, como princípio fundante da caracterização humana formada nos primeiros anos de vida. Abordando diacronicamente a temática, serão analisadas as idéias de outros autores, referenciados por variadas matrizes teórico-metodológicas, para efetuar tal diálogo entre educação e ética. A perspectiva que se pretende tomar abarcará 0 tema do ponto de vista educacional, procurando entretecer 0 relato com o que se compreende ser sugestivo e profundo para a meditação sobre o tema. 
À luz de tal propósito, merece destaque o sentido conferido por $\mathrm{H}$ anna Arendt para a acepção de autoridade como critério distintivo da relação assimétrica entre professor (e as gerações adultas, de maneira geral) e estudantes (ou as novas gerações). Arendt defende, como conceito e pressuposto operatório, a dimensão necessariamente conservadora do ato educativo: compete ao educador preservar do mundo as novas gerações e preservar o mundo das novas gerações - para que estas não destruam o suporte de memória e 0 acervo cultural acumulados pela H umanidade no transcurso de milênios (Arendt, 1979, p. 242-243). Pela reflexão de $\mathrm{H}$ anna Arendt, a dimensão conservadora do ato educativo faz parte da própria ação educativa. Assim compreendendo, a autora desafia o que qualifica como pathos do novo nas teorias pedagógicas, afirmando que o conservadorismo faz parte da própria essência da atividade do educador; dado que preparar as jovens gerações para o 'novo' seria encaminhá-las rumo ao desconhecido: aquilo que elas - quando crescidas - poderão vivificar; e não as gerações que as precederam. Como isso é basicamente impossível, compete à educação familiarizar as jovens gerações com o mundo que lhes preexiste. ${ }^{1} \mathrm{D}$ aí a falácia da idéia de preparação para o novo: "pertence à própria natureza da condição humana o fato de que cada geração se transforma em um mundo antigo, de tal modo que preparar uma nova geração para um mundo novo só pode significar o desejo de arrancar das mãos dos recém-chegados sua própria oportunidade face ao novo" (idem, p. 226).

À luz da reflexão de $\mathrm{H}$ anna Arendt, o máximo que o educador pode e deve fazer é colocar a criança em contato com o acervo/patrimônio cultural historicamente acumulado e preservado. N esse sentido, existiria a dupla tarefa de preservação cultural e humana. Daí a ênfase quanto aos conteúdos clássicos a serem trabal hados com as novas gerações; posto que o professor, "face à criança, é como se ele fosse um representante de todos os habitantes adultos, apontando os detalhes e dizendo à criança: - Isso é o nosso mundo" (idem, p. 239). N essa direção, cabe destacar 0 alerta de $\mathrm{H}$ anna Arendt quanto à dimensão ética e existencial do trabalho em educação:

A educação éo ponto em quedecidimos seamamos o mundo o bastante para assumirmos a responsabilidade por elee, com tal gesto, salválo da ruína que seria inevitável não fosse a renovação e a vinda dos novos e dos jovens. A educacão é, também, onde decidimos se amamos nossas criançaso bastante para não expulsá-las denosso mundo eabandoná-las a seus próprios recursos, etampouco arrancar desuas mãosa oportunidade deempreender al guma coisa 
nova eimprevista para nós, preparando-as, em vez disso, com antecedência, para a tarefa de renovar um mundo comum. (I dem, p. 247)

Finalmente, o presente ensaio procura trabalhar alguns aspectos da meditação e da polêmica contemporânea sobre o tema da ética na educação perante um mundo globalizado: como conciliar a globalidade dos sentidos éticos com a mundialização da cultura de massas e com a tão freqüente defesa da plural idade cultural, como preceito metodológico do pós-moderno modo de agir? Q uais as relações entre a formação escolar do século XXI e a validade do ensino de atitudes, hábitos e valores tidos por universais? $N$ ote-se que o texto aqui desenvolvido abarca a temática por uma perspectiva diacrônica, tendo em vista recordar tópicos do pensamento clássico sobre a interface ética/educação; e, do ponto de vista da pedagogia, identificar o estado atual do debate em nossa momentânea aldeia global.

\section{Ética como aretai : a vida justa e boa}

$\mathrm{N}$ a G récia clássica, a acepção da ética vinha, a dada altura, atrelada a alguns elementos constitutivos que supunham, no conjunto, a acepção de excelência intrínseca à expressão da aretai: bravura, ponderação, justiça, piedade, saúde, força e beleza. D aí decorria, para os gregos, as características distintivas da particularidade humana na correspondência entre corpo e alma. Como bem sublinha Jaeger:

É a partir daqui queo conceito socrático debom, o mais intraduzível eo mais exposto a equívocos detodos os seus conceitos, sediferenciado conceito análogo na ética moderna. Serámaisinteligível para nóso seu sentido grego seem vez de dizermoso bom dissermoso bem, acepção queengloba simultaneamentea sua relação com quem o possui ecom aquelepara quem seébom. ParaSócrates, sem dúvida, o bom étambém aquilo quesefaz ou sequer fazer por causadesi próprio, mas ao mesmo tempo Sócrates reconheceneleo verdadeiramenteútil, o salutar, e também, portanto, o que dá prazer e felicidade, uma vez que é ele que leva a natureza do homem à realização do seu ser. $\mathrm{N}$ a base desta convicção aparecenos a promessa evidente de que a ética é a expressão da natureza humana bem entendida. Estadistingueseradicalmenteda existência animal pelos dotesracionais do H omem, quesão os quetornam o ethos possível. (Jaeger, 1995, p. 535)

A ética era, assim, derivada de tomadas de decisão; decisões postas em prática; prática mobilizada por ação dirigida ao bem, motivada pela busca de uma vida equilibrada e pautada em parâmetros tidos por valorosos. A harmonia, por si, decorreria da própria noção grega de excelên- 
cia (aretai): 0 agir ético, então, corresponderia a um dado exercício da alma, exercício continuado e cotidiano, motivado pela própria suposição da universalidade do bom enquanto bem comum e compartilhado. O ra, se, em Platão (1973), a virtude é posta como uma vocação a ser atualizada, para Aristóteles (1987), a virtude seria uma disposição de espírito, que desabrocha pela força do hábito. Remeter-se ao hábito requer, contudo, valorizar a formação: daí podemos depreender a dimensão pedagógica da ética.

D e acordo com Aristóteles, existem duas espécies de virtude: a intelectual e a moral, sendo que nem uma nem outra estariam dadas à partida: em matéria intelectual, o lugar da formação seria o ensino; em matéria moral, a aptidão para a virtude decorreria da força do hábito, da prática, e, portanto, da ação social. Aristóteles não descarta, porém, o lugar da natureza na obtenção dos dons humanos. Pelo lugar natural, em tudo o que se revela expressão dos sentidos, o homem adquire a potência, a qual será, a seu tempo, exteriorizada em ato. Assim, a visão e a audição são potenciais no recém-nascido, mesmo que este ainda não se valha plenamente dos sentidos. São potenciais que, a seu tempo e progressivamente, serão atualizados na ação. No tocante à virtude, sucederia outro movimento: é pelo exercício que se adquire a prática do bem ao praticar a justiça, tornamo-nos justos (Aristóteles, 1987, p. 27).

pelosatosquepraticamos com os outroshomensnostornamosjustosou injustos; pelo que fazemos em presença do perigo epelo hábito do medo ou da ousadia, nos tornamos valentes ou covardes. 0 mesmo se pode dizer dos apetites da emoção eda ira: uns setornam temperantes ecalmos, outrosintemperantese irascíveis, portando-sedeum modo ou deoutro em igual dadedecircunstâncias. N uma palavra: as diferenças de caráter nascem de atividades semelhantes. É preciso, pois, atentar paraa qualidadedosatosquepraticamos. (Idem, p. 27-28)

Em Aristóteles, a noção de potência remete-se ao futuro reservado pela natureza. A adulto seria, então, a anterior criança que atualizou em ato sua potencialidade original. Tal desenvolvimento intrínseco às novas gerações, de maneira geral, corresponde à atualização de um telos, de um devir, de uma finalidade. É assim que a condição humana pode ser caracterizada como sensível e intelectual em potência. Contudo, para Aristóteles, a potência limitar-se-ia à possibilidade de "produzir o ser em ato" (Abbagnano, 1981, p. 115). A ética seria, portanto, a vida boa enquanto vida justa na esfera coletiva. É na ação social e na relação com os outros que se constitui o fato ético como a desenvolução de um exercício capaz de tornar o homem propenso a conjugar razão e sensibilida- 
de. $\mathrm{N}$ esse sentido, para se tornar bom, deve-se praticar atos bons. $\mathrm{A}$ ética seria, assim, matéria da ação. Aristóteles frisa que o território ético firma-se, por definição, na prática, no hábito e no exercício. N ão se forma o ser ético exclusivamente pelo conhecimento ou pela disposição do intelecto. A ética fala de perto ao espírito e à alma; e só pode ser reconhecida quando praticada:

Por conseguinte, as ações são chamadas justas e temperantes quando são tais como as quepraticaria o homem justo ou temperante; masnão étemperanteo homem queas pratica, esim o que as pratica tal como o fazem osjustos eos temperantes. É acertado, pois, dizer que pela prática de atos justos se gera o homem justo, epela prática deatostemperantes, o homem temperante; sem essa prática, ninguém teria sequer a possibilidade de tornar-se bom. M as a maioria das pessoas não procede assim. Refugiam-se na teoria e pensam que estão sendo filósofos esetornarão bons dessa maneira. $N$ isto seportam, decerto modo, como enfermos queescutassem atentamente os seus médicos, mas não fizessem nada do que estes Ihes prescrevessem. Assim como a saúde destes últimosnão pode restabelecer-secom tal tratamento, aalmados segundosnão setornarámelhor com semelhantecurso defilosofia. (Aristóteles, 1987, p. 31)

Aristóteles reporta-se àquilo que compreende como justo meio ou mediania para referir-se, de modo geral, à noção de ética. A G récia convivia com a acepção de hybris, exatamente referida à ausência de medida e de limites; 0 oposto residiria, portanto, na harmonia e na excelência da aretai (Jaeger, 1995). Aristóteles, ao reportar-se ao ideal do justo meio, enfatiza a moderação como virtude capaz de entrelaçar prudência e 0 discernimento na ação: a medida exata entre dois extremos. 0 ser virtuoso adquire, ao agir, a propensão do caráter educado para a moderação. Podemos emprestar, talvez, a síntese de Abbagnano, ao discorrer sobre 0 conceito da ética em Aristóteles:

A virtudemoral ou ética consistenacapacidadedeescolher o justo meio entredois extremosviciosos, em queum peca por excesso eo outro por defeto. A coragem, queéo justo meio entrea vileza eatemeridade, incidesobretudo aquilo quese deveou não devetemer. A parcimônia, queéo justo meio entreaintemperança eainsensibilidade, diz respeito ao uso imoderado dosprazeres. A liberalidade, que éo justo meio entrea avarezaea prodigalidade, diz respeito ao uso ajuizado das riquezas. A magnanimidade, queéo justo méo entreavaidadeeahumildade, diz respeito à justa opinião de si próprio. A mansidão, queéo justo meio entrea irascibilidadeea indolência, diz respeito àira. (Abbagnano, 1981, p. 123)

Se a escolha da ação é um requisito da prática humana, a sensatez apresenta-se geralmente no lugar intermediário. Ser adepto desse justo 
meio significa não se exceder e, por outro lado, não faltar às disposições do espírito. Entre atos e palavras, os extremos são exatamente elementos impróprios e contrários entre si, um como deficiência e o outro - seu oposto - como excesso. A ponderação, o equilíbrio e a moderação seriam, pois, fonte da sabedoria, entendendo-se por sabedoria sabor e saber, juntos e apurados (D uch, 1997, p. 56). A sabedoria supõe certamente paixão pelo conhecimento. Essa paixão, esse desejo cultural incurável, acarreta para o sujeito cognoscente uma serena inquietação de espírito, uma cumplicidade para com as grandes questões intelectuais de seu tempo, uma harmonia eivada de espírito crítico; e, finalmente, um elevado grau de humildade, típica daqueles que sabem mais e melhor...

A liberdade da vontade do ser humano dirige a ação ética, a qual, por sua vez, reporta-se à plena identidade entre meios e fins da ação. Todo agir coletivo revela-se propício cenário para a prática da ética cotidiana; daí a relevância dada por Aristóteles para a amizade enquanto entrega desinteressada e presente na mútua benevolência, cuja interação não poderia deixar de contribuir para o bem comum. Amizade como escolha do outro; como reconhecimento do outro no outro e como encontro de si mesmo nesse reconhecimento do outro. Amizade como partilha e como projeto: exemplo da possibilidade, talvez, de uma sociedade mais fraterna. A amizade, confluência da ética para a comunhão, supõe a reciprocidade do bem e das fontes do prazer da convivência. A alma inteira se entrega nessa disposição do afeto para a amizade:

fazer desinteressadamenteo bem ao amigo, desejar-Ihelonga vida, desejar viver em sua companhia, compartilhar as mesmasidéias, opiniões egostos, compartilhar alegrias e tristezas - desejar ao outro o que deseja para si mesmo. A amizade só existe entre os prudentes e os justos, sendo por isso condição e conseqüênciada vidajustaqueéa vidana comunidadepolítica. (Chauí, 1994b, p. 322-323)

Em Aristóteles - como bem destaca M arilena Chauí - o exercício da amizade estrutura o próprio ideal da autonomia. Já que aos homens não foi concedida a plenitude divina, pela união mais desinteressada dos mesmos homens entre si, desenvolver-se-ia o movimento em direção a essa liberdade/autonomia, à independência do sujeito para encontrar em si e por si os motivos e as estratégias de ação. Tal autonomia é, contudo, um aprendizado, expresso fundamentalmente na vida voltada para o convívio ético: vida mais feliz e mais harmoniosa. Indispensável para 0 viver coletivo, a acepção de amizade ganha em Aristóteles um estatuto 
bastante elevado para a produção de decisões acertadas sobre o possível e sobre o desejável. A conduta e o ethos da virtude representariam, fundamentalmente, o afastamento humano da irracionalidade das paixões, do domínio dos desejos e das pulsões. A conduta virtuosa e o ethos da 'vida boa' pautar-se-iam pela perseverança quanto à retidão do agir e pela cautela perante as infortunas do acaso.

A educação ética - podemos dizer - supõe um certo disciplinar das vontades, um controle continuado dos instintos e da expressão das determinações externas. A ética é firmada no discernimento necessário entre o possível e o sonhado, na busca escrupulosa de construção de uma vida equilibrada, valorosa e justa, que resiste e recusa o voluntarismo das paixões. N essa trilha, a identificação precisa do sentido da justiça e o discernimento das fronteiras que possibilitam a justa indignação se apresentariam como requisitos fundamentais:

A justa indignação éum meio-termo entreainveja eo despeito, eestas disposiçõessereferem à dor eao prazer quenosinspiram a boa ou máfortuna denossos semelhantes. 0 homem quese caracteriza pelajusta indignação confrange-se com a má fortuna imerecida; o invejoso, queo ultrapassa, aflige-secom a boa fortuna alheia; eo despeitado, longe dese afligir, chega ao ponto derejubilar-se.

(...)

Está, pois, suficientementeesclarecido quea virtudemoral éum meio-termo, e em quesentido devemosentender esta expressão; equeéum meio-termo entre doisvícios, um dos quais envolve excesso eo outro deficiência, eisso porquea suanaturezaévisar àmedianianas paixõesenos atos. D o queacabamos dedizer segue-se quenão éfácil ser bom, pois em todas as coisas édifícil encontrar o meio-termo. Por exemplo, encontrar o meio deum círculo não é para qualquer um, massó para aqueleque sabefazêlo; $e$, do mesmo modo, qualquer um pode encolerizar-se, dar ou gastar dinheiro - isso éfácil; mas fazêlo à pessoa que convém, na medida, na ocasião, pelo motivo eda maneira que convém, eiso quenão é para qualquer um etampouco fácil. Por isso a bondadetanto érara como nobreelouvável. (Aristóteles, 1987, p. 37)

D e algum modo, a essência da ética aristotélica reside justamente na coincidência entre a desejada 'vida boa' e a realização das virtudes. Estas significam a máxima realização em ato da potência humana; ou, nos termos de Xavier Rubert de Ventós, a propósito do tema, a plenitude do ser consistiria - para Aristóteles - a realização mais plena daquilo que já se é. Ventós, contudo, pondera acerca da especificidade da noção de bom para o mundo grego; absolutamente distinta da acepção hoje corrente de 'bom' como aquilo de que gostamos e que nos apetece e do 
'mal' como aquilo que nos causa repugnância (Ventós, 1996, p. 60). Os significados que foram atribuídos pela modernidade à idéia do bom e do belo seriam, no parecer do autor, não apenas divergentes dos conceitos gregos e, particularmente, aristotélicos. $M$ ais do que isso, 0 entendimento moderno do sentido de bom - agora separado da dimensão ética do bem - é relativista e narcisista: "pois reduz toda a questão concreta sobre a bondade objetiva de uma instituição, um governo, uma guerra, a uma questão de gosto. Uns gostam da segregação e outros preferem a integração; a alguns repugnam as guerras imperialistas e outros se comprazem com elas" (idem). Relativismos... N ada mais distante das virtudes aristotélicas.

O ra, efetuada esta ligeira aproximação dos sentidos inscritos na idéia de bem e de virtude em Aristóteles e no mundo antigo, caberia retomar um termo especificamente grego, intrinsecamente ético e carregado de sentido educativo: paideia. Contidos nos múltiplos significados do termo paideia poder-se-ia encontrar, simultaneamente, cultura, cultivo intelectual, instrução, educação, capacidade de aprender, desenvolvimento da memória e, especialmente, da "ânsia de saber" (Jaeger, 1995, p. 558), sem a qual qualquer esforço pedagógico estará fadado ao fracasso. $\mathrm{N}$ ote-se, assim, que a filosofia grega da Antigüidade já pontua a curiosidade intelectual e o desejo de aprender como requisitos para a acepção do verdadeiro ensino; aquele que deixa sua marca, e que parte do também desejo desse comungar o saber aprendido e compartilhar a cultura, com as gerações que a levarão adiante.

\section{A modernidade como pedagogia de uma ética do dever}

0 tempo da modernidade tem, talvez, na filosofia de Descartes sua expressão mais difundida. A busca de um método sistemático como roteiro para investigação racional, a dúvida metódica como anteparo do conhecimento racional, a atitude da crítica frente às dimensões incertas contidas no mundo dos sentidos e das percepções sensoriais remetem à consagração da idéia de razão como motivo e instrumento do conhecimento. 0 século XVIII, com o movimento iluminista, levaria à radicalidade a exaltação da razão como fonte e estratégia para a regeneração coletiva das sociedades. Rousseau, nesse aspecto, torna-se voz dissonante dessa matriz cartesiana, tão cara aos seus contemporâneos, teóricos enciclopedistas. Rousseau, para além de quaisquer aspectos relativos ao conhecimento e à razão, na contracorrente de seu tempo, acentua explicitamente a dimensão da 
vontade humana como verdadeiro sinal da distinção do homem de seu meio natural. Por sua palavras, temos que:

(...) não é pois tanto 0 entendimento que faz entre os animais a distinção específica do homem, mas a sua qualidade de agentelivre A natureza manda todos os animaise 0 animal obedece. 0 homem experimenta amesma expressão, mas reconhece-selivre de concordar ou de resistir; eésobretudo na consciência desta liberdadequese mostra a espiritualidade da sua al ma; porqueafísica explicadal guma maneira o mecanismo dossentidoseaformação dasidéias; mas no poder dequerer ou, antes, de escolher, eno sentimento destepoder só se encontram atos puramente espirituais, que não se conseguem explicar absolutamentenada pelas leis da mecânica. (R ousseau, 1976, p. 33)

D epreende-se do trecho acima transcrito que a tônica do pensamento rousseauniano reside na qualificação do dilema ético como um problema expresso antes na vontade humana do que na razão; mais do que isso, o homem, como ser capaz de tomar decisões, como ser capaz de se afastar da regra prescrita, teria nessa força da vontade seu principal distintivo de humanidade. Tendo na piedade sua virtude originária, 0 homem civil distingue o bem do mal: nessa opção estaria dada a escolha ética. As crianças, assim como o homem no estado de natureza, não conhecem tal distinção: daí a ausência de virtude na bondade natural; portadora apenas da piedade originária. 0 aprendizado da ética virá pelo exemplo, pela revelação, pela imitação. Parte-se do amor de si para desenvolver 0 amor pelo outro. 0 pudor, portanto, nasce do conhecimento do mal. $\mathrm{N}$ os termos de Rousseau, sendo que a amizade costuma ser o primeiro sentimento do jovem educado, será a partir da sensibilidade por sua prática originada que o indivíduo adquirirá "sementes de humanidade" (idem, 1979, p. 242). Sendo a ética, em Rousseau como em Aristóteles, antes uma prática do que um aprendizado conceitual, recomendará o educador do Emílio:

Em uma palavra, ensinai avosso al uno a amar todos oshomens, inclusiveosque o desdenham; fazei com queele não se coloqueem nenhuma classe, mas que se encontreem todas; falai diante dele, ecom ternura, do gênero humano, com piedadeaté, masnunca com desprezo. H omem, não desonreso homem. (Idem, p. 242).

A liberdade residiria, em Rousseau, no coração do homem. Tal sensibilidade seria - note-se - passível de educação. 0 ra, como o homem conteria em si aquele princípio inato de justiça expresso na idéia de piedade, existe possibilidade e necessidade de desenvolver tal dispo- 
sição - de maneira a, para utilizar a expressão aristotélica, transformar a potência em ato. Diz o educador a Emílio, sobre 0 árduo e, por vezes, sinuoso aprendizado da moral:

M eu filho, não háfelicidadesem coragem, nem virtudesem luta. A palavravirtude vem deforça; a força éa baseda virtude; a virtude só pertenceaum ser fraco por naturezaefortepor sua vontade ésó nisto queconsisteo mérito do homem justo; e embora digamos que $D$ eus ébom, não dizemos queévirtuoso, porque não necessita de esforço para agir bem. Para te explicar esta palavra tão profanada esperei que estivesses em condiç̧̃̃es de me entender. Enquanto a virtude nada custapara ser praticada, poucanecessidadesetem deconhecêla. Essanecessidade vem quando as paixões despertam; chegou agora para ti (...). Q ueé então um homem virtuoso?É aquelequesabedominar suas afeições, pois então seguesua razão, sua consciência, faz seu dever, mantém-sedentro da ordem enada o pode afastar dela. Até aqui não era livresenão aparentemente; não tinhassenão a liberdade precária de um escravo a quem se tivesse determinado. Sê agora livre efetivamente; aprendea tetornaresteu próprio senhor; manda em teu coração, Emílio, eserás virtuoso. Eis portanto outro aprendizado a ser feito eesteémais penoso do queo primeiro, porqueanaturezanos libertadosmalesquenosimpõe, ou nos ensina a suportar, mas nada nos diz quanto aos quevêm denós; ela nos abandonaanósmesmos; ela nos deixa, vítimas denossas paixões, sucumbirmosa nossas dores vãs e ainda por cima nos vangloriamos das lágrimas de que nos deveríamosnos envergonhar. Eisa primeira pai xão. (...) É um erro distinguir as paixões em permitidase proibidas, a fim denos entregarmosàs primeiras enos recusarmos às outras. Todas são boas quando as dominamos; todas são ruins quando nossujeitamosaelas. 0 quenoséproibido pelanaturezaélevarmosnossas afeições além denossas forças; o quenoséproibido pela razão équerermoso que não podemosobter; o quenos éproibido pela consciêncianão ésermostentados esim deixarmo-nos vencer pelastentações. (Rousseau, 1979, p. 324-326)

A sabedoria como domínio de si e auto-conhecimento traz pistas para remeter para a educação o debate a propósito da ética. A prudência e o discernimento das paixões, o domínio dos afetos, esse constante aprender a fazer de si próprio seu senhor, é o que demarca o campo do que poderíamos compreender como autonomia da vontade. Assim, a condição humana seria fundamentalmente, em Rousseau, o livrearbítrio e as demarcações de escolhas que, sendo autônomas e espontaneamente engendradas no homem bem formado e bem cultivado, contribuam para orientar o sentido de sua ação prática.

Kant, na mesma direção, apresentará o território da ética como campo da distinção humana, da especificidade e particularidade do homem perante sua circunscrição. Como em Rousseau, para Kant, o homem é 0 animal da natureza destinado a escolher, inclinado, portanto, a eleger 
caminhos e propor trilhas; vocacionado para justificar suas escolhas. A opção pelo bem, em Kant, remete-se ao que o autor qualifica - desde a Fundamentação da metafísica dos costumes - como imperativo categórico; intuição primeira que, posta como dever, torna-se obrigação de consciência. 0 ser humano seria, em certa medida, o sujeito que escolhe as normas que, escolhidas, adquirem validade universal, fazem-se dever de moralidade; tornam-se justa intenção a regular o campo do agir. A vontade moral estaria, pois, em consonância com leis universais irredutíveis, as quais se remeteriam à máxima posta na grande referência da ação prática kantiana: o modo como atuamos no mundo deverá estar de acordo com a noção de bem que nós - seres capazes de discernimento entre o bem e o mal - consideramos universal; ou, por outras palavras, nossa ação deverá traduzir, tanto pelas estratégias adotadas na ação quanto pelos propósitos que nortearam a mesma, as feições que nós - criaturas morais por excelência - gostaríamos de poder tomar como essências de virtude para toda a condição humana.

$\mathrm{N}$ os termos de Kant, ao pensar a ética, eu, sujeito da moralidade, "devo proceder sempre de maneira que eu possa querer também que a minha máxima se torne uma lei universal" (Kant, 1995, p. 33). 0 agir de acordo com virtudes éticas universalmente válidas exigiria o reconhecimento destas últimas. D aí a necessidade do estabelecimento no tocante às atitudes para com os outros, para conosco e para com o mundo - de ordenações do comportamento: imperativos categóricos. Estes fazem por coincidir meios e finalidades do agir do homem: "não se relaciona com a matéria da ação e com o que dela deve resultar, mas com a forma e o princípio de que ela mesma deriva; e o essencialmente bom na ação reside na disposição, seja qual for o resultado" (idem, p. 52). Assim, tais 'mandamentos da moralidade' seriam, por definição, distintos das 'regras da destreza', expressas, sobretudo, na dimensão da técnica e dos 'conselhos da prudência' pertencentes a significados pragmáticos, cujos objetivos seriam o bem-estar e/ou a felicidade do homem em sociedade (idem, p. 53). Agir pela ética não garante felicidade, bem-estar ou êxito. Supõe tão-somente a ação reta, condizente com os mandamentos da moral. Vemos, portanto, em Kant, a separação que não havia em Aristóteles - entre 'ética' e 'vida boa'. Q uando o tema é a moralidade, para Kant, não é o resultado da ação que a determina, mas uma lei que transcende a própria vontade do resultado... O ra, sendo a moral universal, não há hipóteses: eu devo ou não devo; e sei exatamente qual deverá ser a escolha, caso minha opção seja ou não pela ética. A opção pela ética pode não resultar no resultado mais feliz, 
ou mesmo mais justo - em se considerando interesses específicos dos sujeitos da ação; porém a opção pela ética será condizente com dimensões inquestionáveis postas no mandamento/dever da ação reta.

Porque, não contendo o imperativo, além da lei, senão a necessidadeda máxima quemanda conformar-seaestalei, enão contendo ale nenhuma condição quea limite, nada maisresta senão a universalidade de umalè em geral àqual a máxima da ação deveser conforme, conformidadeessa quesó o imperativo nos representa propriamentecomo necessária. 0 imperativo categórico éportanto só um único, queéeste: ageapenassegundo uma máxima tal quepossasao mesmotempo querer que ela setornelei universal. (...) U ma vez queauniversalidade dalei, segundo aqual certos efeitosseproduzem, constitui aquilo aquesechama propriamentenatureza no sentido maislado da palavra (quanto àforma), quer dizer arealidadedas coisas, enquanto é determinada por leis universais, o imperativo universal do dever poderia também exprimir-se assim: age como sea máxima da tua ação sedevesse tornar, pela tua vontade, em lè uni versal da natureza. (Kant, 1995, p.58-59)

A acepção de vontade em Kant supõe a idéia da autonomia do sujeito, e 0 reconhecimento dela advindo, quanto às distinções entre 0 bem o mal. A Fundamentação da metafísica dos costumes expressa, pois, tal convicção quanto à existência de uma "vontade legisladora universal" (idem, p. 73), presente na individualidade da razão autônoma. Kant distingue a heteronomia e a autonomia concernentes ao uso da razão humana por analogia com a idéia de menoridade e de maioridade moral. Em sua Resposta à pergunta: que é Iluminismo?, Kant expressa sua crença no poder do conhecimento e da llustração como fontes de produção de uma autonomia coletiva e de um usufruto mais pleno do "sagrado direito da humanidade" (Idem, 1989, p. 16).

0 esclarecimento trazido pelo poder do conhecimento levaria a uma abertura do entendimento do indivíduo em sua liberdade, sem necessidade de recorrer a guias ou orientações externas, conduzindo o ser humano ao caminho da ilustração, consoante àquilo que o filósofo qualifica por maioridade política e social. A política do lluminismo, pelo abrigo da razão, conferiria ao ser humano a possibilidade de se libertar da tutela e das opiniões dos outros: "não há perigo em permitir aos seus súditos fazer uso público da sua própria razão e expor publicamente ao mundo as suas idéias sobre a sua melhor formulação, inclusive por meio de uma ousada crítica da legislação que já existe" (idem, 1989, p. 18). Porém, a par da crítica, a máxima kantiana exige a obediência: no campo da ética, a obediência radicar-se-ia no imperativo categórico aquele que traz por si um valor intrínseco, não se condicionando a nenhuma hipótese, condição ou interesse. $\mathrm{H}$ averia um interesse público 
acima dos particulares e todas as ações do homem deveriam ser, no âmbito dos valores, situadas em tal vontade legisladora maior, passível de ser reconhecida pela razão individual autônoma. Para isso, como se afirmou anteriormente, é preciso ponderação e equilíbrio de julgamento em, pelo menos, três sentidos complementares:

1. Primeiramente, ao julgar a ação em sua intencionalidade moral, há de se indagar da possibilidade de um poder querer que a máxima de nossa atitude seja passível de ser compreendida com valor de lei universal (Kant, 1995, p. 62).

2. Q uerer e dever, no sentido ético, teriam, em princípio, um único sentido: as ações humanas passariam a ser compreendidas como passíveis de generalização. A cada decisão, no campo da virtude, o sujeito se depara com a reflexão acerca da validade de sua ação no sentido da universalidade que ela traz em si: em tal reflexão estaria posta a decisão ética. Nas palavras de Kant "o princípio da autonomia é portanto não escolher senão de modo a que as máximas da escolhas estejam incluídas simultaneamente no querer mesmo, como lei universal" (idem, p. 85).

3. Finalmente, constituindo a moralidade um território em absoluta sintonia entre o campo das ações e a sujeição a leis universais ditadas pela autonomia da vontade, o ser racional só poderá ser compreendido como um sujeito dos fins, de onde se depreende a absoluta necessidade de as estratégias da ação reconhecerem inequivocamente no homem sempre uma finalidade e jamais uma estratégia ou um meio para o propósito desejado. $\mathrm{H}$ averia, na moral kantiana, total coincidência entre meios e fins. A compreensão da natureza racional como um fim em si acarretaria, consequentemente, a necessidade de entender no ser humano o princípio subjetivo da ação; expresso na máxima: "age de tal maneira que uses a humanidade, tanto na tua pessoa como na pessoa de qualquer outro, sempre e simultaneamente como fim e nunca simplesmente como meio" (idem, p. 69).

\section{O juízo moral da criança e a ação educativa}

Retomando as sentenças kantianas, Piaget, particularmente em sua obra 0 juízo moral na criança, destaca diferentes etapas no que compreende ser 0 desenvolvimento moral das gerações imaturas. Para 0 autor, a autonomia não é um dado de natureza, mas um efeito do ato educativo e, sendo assim, haveria a possibilidade do reconhecimento de níveis mediante os quais o ensino procederia com vistas à constru- 
ção da moral autônoma do indivíduo. Partindo da analogia operatória da relação da obediência às leis morais com a noção de obediências às regras do jogo, Piaget recorda que o pensamento moral, qualquer que seja sua orientação "consiste num sistema de regras e a essência de toda a moralidade deve ser procurada no respeito que 0 indivíduo adquire por essas regras (....) As divergências doutrinárias só aparecem no momento em que se procura explicar como a consciência vem a respeitar essas regras. É esse como que tentaremos analisar..." (Piaget, 1994, p. 23). Em um primeiro momento - destaca Piaget - a criança aprende a obedecer regras ditadas por seus pais, cujos significados lhes são alheios. $M$ ais do que o conteúdo da regra em si, a criança obedeceria à sentença dos adultos que Ihe cercam. Por isso, Piaget parte do estudo dos jogos como fonte de identificação da consciência ou não, por parte das crianças, da razão de ser das regras de ação reta. $N$ esse sentido, 0 autor qualifica os jogos como paradigmáticos para a compreensão da prática normativa, no respeito e na obediência acarretados pelas normas a partir do momento em que são identificadas; para serem, em seguida à compreensão, autonomamente interiorizadas, em seus motivos e nos efeitos inerentes às suas práticas. 0 tempo da formação da moralidade seria condizente com a progressiva passagem da razão alheia para a razão autônoma. Tal passagem teria uma dinâmica própria, evolutiva, tanto biológica quanto social, tanto derivada da razão quanto da sensibilidade.

O bservando o jogo das crianças, Piaget nota primeiramente uma justiça retributiva: 0 grupo de crianças costuma dar conta de afastar 0 trapaceiro do jogo, de castigar o menino que agrediu gratuitamente 0 colega etc. Para Piaget, tal interação infantil contém um elemento que nem sempre corresponde à relação da criança com os adultos. Entre iguais, a criança compreende a razão de ser das normas. Q uando é punida pelo adulto, a criança apenas expia sua culpa: 0 argumento de autoridade e o sentimento do remorso passam a calar em sua alma. Q uando se trata do jogo entre crianças em igualdade de condições, modificam-se as razões e a própria lógica interior ao sentido de justiça estabelecido: como se a moral da autoridade fosse, pouco a pouco, sendo mobilizada para uma moral do respeito mútuo, da solidariedade entre iguais, da reciprocidade. Q uanto mais crescida a criança, menos sujeita ela estará à exclusividade de uma moral calcada essencialmente no argumento de autoridade. Paralelamente ao desenvolvimento infantil, haveria uma submissão, não mais aos adultos, mas a uma voz/regra interior - que se lhe assemelha à regra do jogo. Tal respeito à norma interna remete a uma progressiva conquista da moral autônoma. 
Como a criança chegaráà autonomia propriamentedita? Vemos surgir o sinal quando ela descobrequea veracidadeénecessárianas relações de simpatia ede respeito mútuos. A reciprocidade parece, neste caso, ser fato de autonomia. Com efeito, há uma autonomia moral, quando a consciência considera como necessário um ideal, independente dequal quer pressão exterior. 0 ra, sem relação com outrem, não há necessidade moral: o indivíduo como tal conhece apenas a anomia enão a autonomia. Inversamente, toda relação com outrem, na qual intervém o respeito unilateral, conduz à heteronomia. A autonomia só aparececom a reciprocidade, quando o respeito mútuo ébastanteforte, para queo indivíduo experimenteinteriormentea necessidade detratar os outros como gostaria de ser tratado. (Piaget, 1994, p. 155)

D aqui decorre a necessidade de as gerações adultas pensarem acerca do ensino/aprendizado da moral, antes de colocar em ação princípios de conduta, tantas vezes infundados, arbitrários ou meramente convencionais. Será que nós, adultos, sabemos o que fazemos quando nos pomos a educar nossos filhos para o campo dos valores? U sualmente, confundese ética com civilidade. 0 aprendizado do viver em sociedade, as boas maneiras convencionalmente apropriadas, não dão conta do juízo moral a se fazer a propósito do mundo, das relações humanas, das mazelas sociais. A família, por vezes excessivamente preocupada com a transmissão de modos de conduta, de atitudes, de um bem se comportar em público, torna-se, com freqüência, 'distraída das coisas mais importantes'. Será que, ao educar, enfatizamos suficientemente o tema do respeito ao outro; ou apenas sublinhamos a ordem de silêncio perante a voz do adulto? Será que ouvimos os porquês de nossas crianças? Será que nos damos ao trabalho de estarmos suficientemente atentos para ficarmos zangados na hora certa, com a pessoa certa, na proporção adequada como recomendava Aristóteles?

A sociedade contemporânea tende a afastar-se do sentimento de infância que vincou a modernidade. $\mathrm{H}$ oje crianças e adultos vestem-se e, por vezes, se comportam do mesmo modo; assistem com freqüência aos mesmos programas televisivos; têm, na mesma medida, acesso às informações da Internet. 0 sentimento de infância que caracterizou 0 mundo moderno tinha por pressuposto a idéia de que as novas gerações são tão inocentes quanto corruptíveis. Assim, passou a haver um certo pudor e a conseqüente preservação das crianças com relação às fronteiras de um universo adulto, para o qual se considerava que elas não estariam ainda preparadas.

$\mathrm{N}$ a Idade M édia, pouco existia do reconhecimento da especificidade infantil. 0 mundo moderno procurou compreender a criança 
na criança; e não apenas o adulto que nela vinha incompleto. Com isso, surge uma certa sensibilidade social para com a infância, que está muito firmada na trajetória da civilização ocidental. Contudo, neste limiar de milênio, há quem acredite que essa situação se inverte. O s veículos de comunicação de massa e a indústria cultural produziram novas referências, mediante as quais volta a se tornar algo impreciso a fronteira que separa o mundo da criança e o mundo do adulto. As jovens gerações são cada vez mais cedo introduzidas no que pode haver de corruptor e de vicioso no mundo dos adultos. Ao mesmo tempo em que as crianças passam a se tornar precocemente adultas, o campo da maturidade, desvalorizado, apregoa, com inaudita ênfase, o desejo de retomada da adolescência. Adultos e crianças: todos desejando aparentar adolescência. Caberia perguntar, em tal cenário nebuloso, onde ficaria a responsabilidade em relação ao mundo. Caberia indagar a quem compete transmitir, preservar e fazer existir os valores e os conhecimentos acumulados.

Educar é, inequivocamente, invocar e evocar valores: há valores generosos e valores perversos. U ma sociedade de consumo, excessivamente pragmática e utilitarista como parece ser esta nossa aldeia do conhecimento global, poderá construir um campo de valores alternativos e suficientemente generosos? São infundadas as sentenças que ainda apregoam a igualdade, a liberdade e a fraternidade como princípios e como método da vida em democracia? Como ser livre sendo igual? Q uais os impasses entre os clássicos direitos do homem e o tão atual chamamento à tolerância? Q uais as relações entre os níveis de cultura - clássica/erudita; popular/espontânea; massiva/de indústria cultural? Como pensar as interfaces do projeto escolar à luz dos incontáveis recortes culturais presentes em cada sociedade? Como se dá a relação entre escola e família no mundo contemporâneo? Como pensar o universo dos direitos com a necessária formação para os deveres?

Supor um propósito ético em qualquer projeto educativo remete-nos à acepção primeira de uma formação humanista; um voltar-se para o conhecimento desinteressado, ele mesmo compreendido como imperativo categórico da ação educativa. N ão é possível educar sem ensinar. Porém, a instrução exclusivamente não educa; não prepara para a sabedoria. Como vimos, originariamente, o termo sabedoria contempla em si saber e também sabor. D eve-se sentir o sabor do conhecimento. M as é preciso que, em educação, se tenha o desejo de ir sempre além. 0 conhecimento e a sabedoria podem ser complementares quando o professor se torna mestre. 0 mestre faz mais do que colocar os 
estudantes em contato com o conhecimento acumulado. 0 mestre transmite 0 saber, mas inscreve na transmissão sua própria marca pessoal; seu sinal. M ostra caminhos e revela segredos, com suor e com sangue descobertos.

M estre é aquele que se mostra capaz conduzir a adesão da juventude para o campo das virtudes e para o campo do saber: com palavras de rigor e com gestos de afeição; com desenhos de utopia e com a radicação da experiência; com razão e com o coração. Q uando G eorges G usdorf indaga dos educadores "professores para quê?" (1970), diz o seguinte: a "indecisão fundamental corresponde a um dos dramas secretos do mestre. Entre aquele que o é autenticamente e a falsa testemunha não há, talvez, outra diferença: o verdadeiro mestre duvida da sua capacidade mesmo quando esta é unanimemente reconhecida por aqueles que 0 rodeiam" (Gusdorf, 1970, p. 154). A palavra-testemunho da verdadeira mestria torna-se lição - no sentido medieval do termo -, senha para que o discípulo, pelo próprio ato de ser despertado, descubra a si mesmo e à sua humanidade; desenvolva suas habilidades; transforme em realidade seu potencial. $\mathrm{N}$ a trilha da obra-prima de Gusdorf, o verdadeiro ensino fala também por seus silêncios (idem, p. 143). Em tal movimento, a mão do mestre acompanha seu aluno, com a autoridade que seu lugar Ihe confere, ainda que, para além de palavras, esta traga muito de gestos e de silêncios: auctor; ou aquele que cria algo.

N os termos de Lluís D uch, "o bom uso da tradição é um negócio diretamente relacionado com o exercício da autoridade, sobretudo uma autoridade que se há de transmitir e de fazer vigorar no presente, enquanto fator essencial para a maduração, crescimento e desenvolvimento das pessoas concretas" (D uch, 1997, p. 66). Retomando Piaget e H uizinga, Duch coloca na capacidade lúdica um dos elementos mais importantes da configuração da plasticidade humana; do que resulta a capacidade do homem para aprender. $\mathrm{H}$ averia, pois, uma antropologia possível de tornar o passado e a experiência vivida peças relevantes para 0 jogo da vida presente. Duch destaca, para tanto, a necessidade operatória de se pensar o tempo como se de uma diversão el e se tratasse. Partindo da capacidade humana para a admiração e, em seguida, talvez, para a indignação, 0 autor aqui se distancia da idéia de tempo como uma linha evolutiva cronológica, presa exclusivamente à dimensão das regularidades, para dar o devido destaque a uma pedagogia que, se é um tempo de espera da previsível continuidade, também é da expectativa de uma projeção e uma aposta no futuro; futuro sempre indeterminado, pautado pela promessa do acaso e do inesperado... 
Em algum sentido, retomamos aqui a acepção grega de kairós, mediante a qual a idéia de tempo reside no instante que se privilegiou, na oportunidade em que se mergulhou... Assim, determinados a viver 0 tempo também pela magia do instante, será possível engendrar uma pedagogia onde a esperança deixe de ser apenas uma palavra de efeito. $M$ ais do que isso, a esperança do educador supõe construção de um território de crenças compartilhadas, onde a igualdade de oportunidades ancore a livre manifestação dos talentos; onde a solidariedade e a fraternidade sejam os ternos contrapontos à necessária inscrição da identidade individual como preceito metodológico da sociedade cidadã.

Pensar a universalidade e o coletivo como pressupostos em que se radicam o específico, o efêmero e o pluralismo requer a edificação de uma ética pública que talvez também esteja posta à prova da escola, passando pela sala de aula; ética esta que credita às gerações mais jovens as esperanças de tempos melhores. E que alicerça sua própria esperançal expectativa nos pilares de um triplo presente, expresso na atualidade que experimentamos quotidianamente, no passado como memória atualizada e no futuro como um leque sempre aberto de possibilidades e de construções (M artins, 1998, p. 74). A educação para a ética se firmaria mediante a reafirmação dos preceitos da democracia e, ao mesmo tempo, mediante a ampliação e o reconhecimento de um alargamento do campo desses direitos que, quanto mais coletivos, tendem a ser mais universais. Pensar a universalização dos direitos é, contudo, atentar para a necessidade do reconhecimento das especificidades, das desiguais manifestações do território da cultura. É preciso, como destaca Guilherme d' O liveira $M$ artins, dar, sim, lugar ao diferente. $M$ as é imprescindível, para tanto, que este diferente esteja necessariamente inscrito em um "universalismo onde todos caibam" (idem, p. 83). Educar requer compromissos; compromissos supõem pactos; pactos remetem-nos, como por um eterno retorno, ao contratualismo como base da acepção de direito, de dever e de ação moral no mundo contemporâneo:

0 pluralismo deveser, destemodo, assumido no sentido forte, enão no sentido fraco - estamosperanteum diálogo aberto, em queosval oreséticosedecidadania não podem ser esquecidosou desvalorizadose em queas diversidadesculturaisse interpenetram. E, sefalarmos devalores, referimo-nos, antes de maisnada, aos que fundamentam a democracia, considerando esta ponto de encontro e de afirmação da dignidade, da autonomiae da responsabilidade. A democracianão pode cultivar, assim, a neutralidade sobre os seus fundamentos e sobre a sua legitimidade (...). D efato o queestáem causaéa procura deuma posição equilibrada entreo quedistingueeo queunea humanidade. (I dem, p. 82) 
N orbert Bilbeny, a propósito, ao debater o dilema ético intrínseco às sociedades contemporâneas em virtude do impacto do discurso acerca das identidades, das diferenças e da pluralidade cultural, defende 0 que qualifica por minimalismo ético; qual seja, aquele que se coloca frente à vida social como um 'mínimo comum' fundado nos inalienáveis direitos fundamentais, a partir dos quais poderão conviver todos os outros direitos concernentes à diversidade ou às distintas especificidades. Para esse autor, os tempos que correm exigem a redução da universalidade dos valores a um mínimo denominador comum, expresso, para além da noção de racionalidade autônoma, em preceitos como os da reciprocidade, da solidariedade, da reflexividade e, até, da sensibilidade. 0 mundo contemporâneo exigiria, nos termos de Bilbeny, novos modos de olhar, sem que, para tanto, nós abdiquemos do reconhecimento de nós mesmos no outro e do outro em nós mesmos - ainda que o eu e 0 outro sejam tão diferentes quanto iguais. H averia, para a compreensão do mínimo comum da ética, um dado primado do campo sensível e da prática da ação moral, o que retomaria - ainda que não de maneira manifesta - a vertente de uma moral pensada como "vida boa" em sociedade. $\mathrm{N}$ os termos do autor:

(...) pensar ou representar mediante conceitos moraisé, a seu modo, fazermonos presentes no outro, tornarmoso outro presenteem nós mesmos eapresentar, assim, aos sentidos, um reconhecimento. $N$ ão énenhum círculo vicioso; éa intersecção de planos que constitui cada realidade pessoal e por meio da qual cada um distribui, com maior ou menor acerto, seu patrimônio moral. 0 solhos e as mãos ajudam a fazer aética, mas a ética ajuda também a tornar visível etangível o mundo que vemos etocamos. (Bilbeny, 1997, p. 190)

\section{A ética no justo meio: entre o dever ea felicidade}

Victoria Camps qualifica o conflito ético como um dilema entre responsabilidades que, por vezes, tem por ponto de partida a divergência entre princípios contraditórios, porém válidos e competitivos entre si. Assim - sugere a autora - é necessário que a concepção de moralidade não seja tão abstrata a ponto de se desvincular por completo de seu contexto de produção. A cerca do tema, Camps atenta para 0 que reputa ser traduções de modos de viver em sociedade, as quais seriam, em si, tão diferentes quanto complementares. $\mathrm{H}$ á, no parecer dessa autora, duas perspectivas morais, consoantes a hábitos herdados e tradições culturais acumuladas pelos dois gêneros: uma ética da justi- 
ça, com matriz masculina; e uma ética do cuidado, de origem feminina. Para cada um desses modos de agir, no campo da ação moral, haveria necessidade de um aprendizado específico, de uma pedagogia da razão, por um lado; e da sensibilidade, por outro. 0 objetivo da educação seria, para Camps, uma atualização/negação da máxima de Píndaro na Grécia arcaica: "torna-te o que tu és". Como teórica da política, Camps explicita o sentido de tal sentença: "de acordo com a fé aristocrática que professa o poeta, a virtude não se aprende, leva-se no sangue. Chegar a ser o que se é consistiria em não trair nem deixar de aproveitar a nobreza e o lugar que, desde o berço, se possui" (C amps, 1996, p. 145). A modernidade reservou papel oposto para o lugar social da educação: exatamente o de romper, pela dialética, com tal fatalismo elitista e aristocrático.

Educar, hoje, é e deve ser, na contramão da sentença de Píndaro, tornar a condição humana em sua plenitude ao alcance de todos; nem que para isso sejam desafiadas as determinações do contexto social; nem que para isso se deva lutar contra algum limite da hereditariedade. Tal desafio supõe um dado ideal de humanidade; uma concepção clara de virtude; e um lugar explícito para a recolha e seleção do saber acumulado com vistas à transmissão cultural. Victoria $\mathrm{C}$ amps sublinha, em sua reflexão acerca do espaço público das virtudes, que "ter uma identidade é conferir unidade à própria vida, recolher o passado e projetá-lo adiante, fixar valores, marcar continuidades e transições. Enfim, fazer da própria existência uma narração com sentido" (idem, p. 146). Assim concebida, contudo, a identidade supõe o cruzamento de três níveis distintos nos quais a marca da individuação se imprime: a H umanidade toda como pressuposto; a comunidade como pertença; a pessoa como individualidade. Cada uma dessas esferas teria, simultaneamente, um dado grau de autonomia e um significativo nível de subordinação umas às outras. Ser livre, assim, não pode prescindir da demarcação da singularidade; mas não pode, pelo lado oposto, prescindir do reconhecimento da máxima do bem comum como objetivo maior da ação em sociedade. Somente pelo justo meio, talvez pela mediania aristotélica, a condição humana se inscreve plenamente no sujeito. A democracia como método requer o complemento da tolerância, como exigência de adequação ao bem da coletividade; tal imbricação contempla em si "a atitude distante do espectador e o compromisso responsável do homem prudente" (Camps, 1995, p. 89).

Tomando como essencialmente coletiva a ação moral, Camps retoma Kant especificamente no que este postula como dever da ação 
reta universal e retoma também Aristóteles na prospecção de uma "vida boa" como resultado da ação moralmente defensável. Porém - reconhece a autora - tanto a universalização dos pressupostos morais quanto a correlação da virtude ética com a felicidade não passam de ficção, em termos da prática histórica. 0 próprio interesse coletivo é histórico e há valores tão válidos quanto contraditórios entre si. Sob tal aspecto, não haveria consenso moral, tomadas as culturas em suas diversidades históricas, geográficas e simbólicas. Por isso, a noção de pacto como instrumento para tornar a justiça um artifício operatório faz-se ainda apropriada e estratégica para a reflexão ética contemporânea:

0 que em nós há de divino nos capacita a esperar ocasiões de felicidade, e reconhecêlas quando aparecem. Trata-se, então, de outra noção defelicidade, a que nos deixam os românticos da qual decorre a própria idéia que se tomou como ponto de partida: a felicidade como obra, enérgeia, vida ativa. (...) ser ativo éo destino do ser humano. É nos momentos deatividadeplena, deH umanidade completa, de saturação humana, que se en contra a felicidade. N ão éa beatitude dos deuses: éo desigual acontecer humano que, devez em quando pode dizer como Fausto: 'detém-te, formoso instante, pois me fazes feliz'. A felicidade é instantânea porque consiste na coincidência contigentedos objetos com nosso eu. A condição da felicidadeéd esfrutar do instante sem adormecer nele, porquequem adormece perece. A eudaimonia, o bom daimon éum dom, mas freqüentee reconhecível. Recordável. Reside nisso aquilo quejamais desejaríamos esquecer ou perder: a narração da vida tal como gostaríamos que ela fosse. (Idem, p. 139)

A ética é uma questão em aberto, como em aberto são sempre os grandes temas que tocam a fundo a condição de ser humano. Educação e ética são dois pólos de uma mesma construção: um mundo mais fraterno e mais saudável, para o indivíduo e para a coletividade. Sendo o homem o único animal capaz de fazer promessas, temos no ser humano um possível cumpridor de leis que a si e aos outros - em interação - estabelece. Cumprir tais leis significa seguir a força da vontade autônoma; suspender as paixões até o limite do possível. Significa, também, um continuado exame dessas leis, sujeitas, em alguma medida, a periódicas revisões.

A ética, finalmente, é crença e é pacto; é pressuposto e é compromisso; é aprendizado e é experiência; é hábito e é disciplina; é indagação e é convicção; é suficiente e provisória, como a vida. E, sobre essa utopia de uma ética, a um só tempo, fraterna e pública, faço minhas as palavras do poeta português Fernando Pessoa, com as quais eu concluo: 
Q uem sabe o queéaalma?/ Q uem conhecequealma hánascoisasque parecem mortas. / Q uanto em terra ou em nada nunca esquece. / Q uem sabe se no espaço vácuo há portas?/ O sonho quemeexortas a meditar assim a voz do mar, / Ensina-mea saber-temeditar.

Recebido para publicação em agosto de 2001.

\section{N ota}

1. “(...) o que quer que o mundo adulto possa propor de novo é necessariamente mais velho do que eles mesmos. Pertence à própria natureza da condição humana o fato de que cada geração se transforma em um mundo antigo, de tal modo que preparar uma nova geração para um mundo novo só pode significar o desejo de arrancar das mãos dos recém-chegados sua própria oportunidade face ao novo" (Arendt, 1979, p. 226).

\section{Ethics AND CLASSICAL EDUCATION:}

\section{VIRTUE AND HAPPINESS IN THE GOLDEN MEAN}

ABST RACT: The present study is an in-depth discussion of the interface between educational and ethical problems, understanding pedagogy as the art/sci enceaiming at good education/instruction/training. For thispurpose, the text will summon concepts from Aristotle's ethics. I mmersed in Classical Greek Thought, it will attempt to rescue a term which is originally interdisciplinary- paideia. $\mathrm{N}$ ext, this essay triesto highlight someaspects of the illuminist concept of the theme, taking advantage of the Kantian notion of categoric imperative, which had been preceeded by Rousseau's opinion asserting that will - and not reason - would be the distinctive feature of the human race in a natural environment. Piaget's idea of reciprocity ethicsis also evoked here. Through a diachronic approach of the theme, concepts of classical authors who havedebated the relationship between ethics and education will beanalyzed, focusing on the sense $\mathrm{H}$ anna Arendt conferred to authority asa di stinctive criteria of theasymmetric relationship between educators (adult generations) and students (new generations). As an operating concept and assumption, Arendt advocates that the educational act necessarily entailsa conservative dimension: the mission of educators is to protect the new generations from the world and the world from the new generations - so that they do not to destroy the accumulated supports and cultural heritage.

Key words: Education; Ethics; Philosophy of education; Pedagogy.

\section{Referênciasbibliográficas}

ABBAGN AN O, N . \& VISALBERGUI, A. História da pedagogia. Vol. I. Lisboa: Livros H orizonte, 1981. 
AREN DT, H anna. "A crise na educação". In: Entre o passado e 0 futuro. São Paulo: Perspectiva, 1979. p. 221-247.

ARIST ÓT ELES. "Ética a N icômaco". Coleção O s Pensadores, vol. II. São Paulo: N ova Cultural, 1987.

BAU M AN, Zygmunt. Ética pós-moderna. São Paulo: Paulus, 1997.

BARROS, Roque Espencer M aciel. M editação sobre Rousseau. São Paulo: Centro Regional de Pesquisas Educacionais, 1963.

BILBENY, N orbert. La revolución en la ética: $H$ ábitos y creencias en la sociedad digital. Barcelona: Editorial Angrama, 1997.

CAM PS, Victoria. Ética, retórica, política. 2ae ed. M adrid: Alianza Editorial, 1995.

. Virtudes públicas. 3a ed. M adrid: Espasa Calpe, 1996.

CH AN GEU X, Jean-Pierre (O rg.). U ma ética para quantos? Bauru: Edusc, 1999.

CH AUÍ, M arilena. Convite à filosofia. São Paulo: Ática, 1994a.

. Introdução à história da filosofia: D os pré-socráticos à Aristóteles. Vol. I. São Paulo: Brasiliense, 1994b.

DELLA VO LPE, Galvano et. al. M oral e sociedade. 2ā ed. São Paulo: Paz \& Terra, 1982.

DESCARTES. Discurso do método. 3a ed. M ira-Sintra: Europa-América, 1986.

DU CH, Lluís. La éducación y la crisis de la modernidad. Barcelona: Paidós Ibérica, 1997.

DUPAS, Gilberto. Ética e poder na sociedade da informação. São Paulo: Unesp, 2000.

GUSD 0 RF, G eorges. Professores para quê? Lisboa: M oraes, 1970.

ITALO CALVIN O. Por que ler os clássicos. 5ạ ed. São Paulo: Companhia das Letras, 1998.

JAEGER, Werner. Pai deia: A formação do homem grego. São Paulo: M artins Fontes, 1995. 
KAN T, Immanuel. Fundamentação da metafísica dos costumes. Lisboa: Edições 70, 1995.

- Resposta à pergunta: Q ue é o lluminismo? A paz perpétua e outros opúsculos. Lisboa: Edições 70, 1989.

KREM ER-M ARIETTI. L'Éthique. 2a ed. Paris: Presses U niversitaires de France, 1987.

M ART IN S, G uilherme d'O liveira. Educação ou barbárie? Lisboa: G radiva, 1998.

$\mathrm{NOHL}, \mathrm{H}$ erman. Introduccion a la ética: Las experiencias éticas fundamentales. 6ạ ed. M éxico: Fondo de Cultura Económica, 1993.

N Ó V O A, António (O rg.). Profissão professor. Porto: Porto Editora, 1991.

PESSO A, Fernando. O bra poética. Vol. único. Rio de Janeiro: Nova Aguilar, 1983, p. 116.

PIAGET, Jean. 0 juízo moral na criança. São Paulo: Summus, 1994.

PLATÃ O. Górgias. In: Górgias / O Banquete/ Fedro. Lisboa: Verbo, 1973.

RAPH AEL, D. D. M oral philosophy. 2a ed. Oxford: Oxford University Press, 1994.

RO USSEAU, Jean-Jacques. Discurso sobre a origem a fundamentos da de sigualdade entre os homens. M ira-Sintra: Europa-América, 1976.

RO USSEAU, Jean-Jacques. Emílio ou Da educação. 3ạ ed. São Paulo: D ifel, 1979.

VAIDERGORN, José (O rg.). 0 direito a ter direitos. Campinas: Autores Associados, 2000.

VENTÓS, Xavier Rubert de. Ética sin atributos. Barcelona: Editorial Anagrama, 1996. 